\title{
Perceived Impact of the Global Financial Crisis on Social Grant Recipients in the Eastern Cape, South Africa
}

\author{
Pius Tangwe Tanga, PhD \\ Professor, Department of Social Work / Social Development \\ University of Fort Hare, PB X1314, Alice 5700, South Africa \\ Email: tanga8_2000@yahoo.co.uk/ptangwe@ufh.ac.za \\ Magdaline Nji Tangwe \\ Faculty of Education, University of Fort Hare \\ PB X1314, Alice 5700, South Africa \\ Email: njimado@yahoo.com
}

\section{Doi:10.5901/mjss.2014.v5n2p277}

\begin{abstract}
South Africa has one of the highest rate of income inequality and the highest level of absolute poverty. Government's primary social welfare objective is focused on poverty alleviation and halving poverty by 2015. Social assistance is one way of achieving this goal. The aim of this study was to examine the perceptions of social grants recipients on the impact of the 2007/2008 financial crisis on their households. Data were collected from 1100 social grant recipients from 37 communities using a semi-structured questionnaire. The findings show that the majority of respondents were recipients of child support grant and females constituted the bulk. Most of the respondents revealed that the grant money was meeting their household and other needs before the financial crisis. However, the capacity to meet these needs slightly dropped during and after the crisis. The crisis has continued to pose a serious challenge in meeting these household needs. It is argued that females were making more household use of their grant money than males as they are regarded as central figures in African households. The 2007/2008 financial and the 2011 Euro zone crises have contributed significantly to the continuous deterioration of socioeconomic conditions of social grant recipients. The paper recommends certain actions to ease rural household dependent on social grants.
\end{abstract}

Keywords: Social grant, Eastern Cape, household income, financial crisis, poverty

\section{Introduction}

A component of the mission of the Department of Social Development in South Africa is to provide an efficient and compassionate social welfare system which is aimed at the eradication of social welfare problems through the implementation of social welfare interventions that will bring maximum benefits to social welfare objectives. The overall aim of this is to increase life expectancy and have an acceptable quality of life for every South African. This is hinged on the principles of universality, social justice and equity as enshrined in the Bill of Rights of the Constitution (Republic of South Africa, 1996). More specifically, the Department of Social Development has one of the core mandates to minimise the impact of deteriorating socio-economic conditions of marginalised groups. With this in mind, the government introduced social grants as supplements to the already existing traditional means of meeting individual needs. It was believed that a combination of these local means of livelihood and social grants would provide good quality of life of recipients, especially people in the rural areas. Unfortunately, this seems not to have been the case, especially with the lack of job creation and opportunities in the rural areas and the current and unbearable rising cost of living, which was orchestrated by the 2007/2008 global financial crisis. In the face of these, this paper examines the impact of the financial crisis on the recipients of social grants.

Social grants are provided by the South African government with the aim to provide a minimum level of income to marginalised groups such as the poor, orphans, elderly, and disabled people. They are provided to those who are unable, whether temporarily or permanently to cope with the problems of everyday living. These grants normally place a high value on keeping families together in their local communities through the African spirit of sharing and reciprocity (Tanga, 2013). The government is grappling with high unemployment rate and escalating cost of living brought especially 
by the global financial crisis. The financial crisis referred to here is the global financial crisis which began in 2007/2008. In assessing the impact of the global financial crisis on social grants recipients, the main research questions were: What were the main types of grants received by respondents? How adequate was the money from social grants in meeting household needs before and after the crisis? How did the crisis impact on the living conditions of the recipients? This is assessed through the perceptions of recipients by comparing their situation before the crisis and during/after the crisis.

\section{Social Grants and Poverty in South Africa}

South Africa has one of the high levels of absolute poverty whereby households are experiencing poverty or are vulnerable to poverty (Altman, Hart \& Jacobs, 2009). The country is ranked amongst the countries with the highest rate of income inequality in the world after Mexico (Organisation for Economic Cooperation and Development - OECD, 2010) with a Gini-coefficient estimated at 0.66; one of the highest in the world (Bhorat \& Van der Westhuisen, 2010). Poverty alleviation is one of the primary objectives of social welfare policy (Republic of South Africa, 1997). The government therefore decided to halving poverty between 2004 and 2014 (Altman, Hart \& Jacobs, 2009). To achieve this aim, the government introduced a variety of poverty alleviation measures, social assistance being one of them. Social assistance aims to assist vulnerable groups of citizens who are unable to provide for their own minimum needs and this is mainly through various grants. It has been noted that social grants have been able to alter levels of inequality marginally and have reduced poverty among the poorest households in South Africa (OECD, 2010). These have continued to be a major source of poverty reduction for millions of South Africans with over 16 million recipients with an annual growth rate of 15.92\% (South African Social Security Agency - SASSA, 2013). There are seven types of social grants in its social assistance system which are all subject to means tests and include: old age grant, disability grant, war veterans grant, foster care grant, care dependency grant, child support grant, and grant in aid (an additional grant for recipients of old age, disability or war veterans grant who are unable to care for themselves) (Department of Social Development, 2009). Grants can significantly improve the status of households, especially in communities where social reciprocity plays such an important role. This is enshrined in Section 27(1) (c) of the Constitution of the Republic of South Africa, 1996 which states that:

\footnotetext{
Everyone has the right to have access to social security, including, if they are unable to support themselves and their dependents, appropriate social assistance. The state must take reasonable legislative and other measures, within its available resources, to achieve the progressive realisation of each of these rights.
}

According to Statistics South Africa - Stats SA (2013), food poverty line (R305 per capita per month) for headcount is $26.3 \%$, poverty gap is $8.5 \%$ and poverty severity is estimated at $3.8 \%$. Poverty in South Africa is unevenly distributed among the nine provinces as follows: the Free State (33.1\%), Eastern Cape (30.8\%), and Mpumalanga (29.4\%) have the highest poverty rates, while Limpopo (18.1\%), KwaZulu-Natal (22.7\%), Eastern Cape (24\%) and Gauteng (25\%) have the lowest (Statistics South Africa, 2013). Although poverty is experienced across racial groups in South Africa, it is endemic among Black South Africans where it is estimated that three children in every five live in poor households. The Eastern Cape Province is one of the poorest provinces in South Africa with about 27\% of those who are likely to be ultra-poor of the $30.8 \%$ of people living in poverty (Stats S A, 2013). The majority of these poor people are living in the former Bantustan areas. Nonetheless, there is significant poverty in the urban areas, especially with the springing up of townships and informal settlement populations. Poverty is multi-dimensional and characterised by a lack of access to opportunities for a sustainable livelihood including income, assets, skills, knowledge, self-confidence and access to decision making.

\section{South African Social Grants in Historical Perspective}

During the apartheid regime only white South Africans were given protection against poverty and vulnerability in the form of social pensions, while black South Africans were excluded through discriminatory policies (Pelham, 2007). The 1928 Old Age Pensions Act provided grants in the form of social pensions to Coloureds and Whites while the Blacks and Indians were initially excluded because it was believed that Blacks would normally get security from their rural kinship at old age (Gutura, 2012). However, blind and old age pension was extended to Blacks and Indians in 1944 (Bhorat, 1995). Whites were receiving an amount five times higher than that for Africans, while coloureds and Indians received half as much as Whites. Coloureds and Whites also benefited from the disability grant introduced in 1937 while it was extended to Blacks and Indians in 1947 (Legido-Quigley, 2003). 
During the period 1948-1961, the gap between White and African pensions widened considerably. By 1987, African grants were 17 per cent of White grants (Community Agency for Social Enquiry - CASE, 2000). The Social Assistance Act of 1992 made provision for the extension of all social security measures to all South Africans on an equal scale and de-racialise access to state grants (Vorster, Rossouw \& Muller, 2000). The African National Congress (ANC) led government introduced the principle of parity in social pensions in 1993. The post-apartheid government moved from residual and institutional models of welfare policy to developmental social welfare, focusing on needy people who were excluded from mainstream welfare and social security systems. The focus was on moving people out of poverty and not only on the construction of social security for prevention, social compensation and income distribution, but on poverty alleviation as well (Republic of South Africa, 1997).

There was a challenge for the new ANC government in 1994 to transform the existing fragmented social security system into one that was based on comprehensive coverage for the whole population. The approach then shifted to the concept of developmental social welfare with emphasis on social development (Midgley, 1996). The newly elected democratic government had to reformed and amalgamated the apartheid-created structures which consisted of 14 separate social security systems each with its own structures, rules, administration and so on (Department of Social Development, 2002). This amalgamation was to secure equal access and the same quality of service for all South Africans. There was also the introduction of some provincial flexibility and autonomy, following the principles of efficiency, effectiveness and fraud prevention (Committee for the restructuring of Social Security, 1997). The White Paper on Social Welfare (Republic of South Africa, 1997) contained the policy framework for restructuring social welfare in South Africa. The Social Assistance Act of 2004 makes the national government responsible for social security grants initially under the national Department of Social Development. This rule has since been taken over by the establishment of the South African Social Security Agency (SASSA) since 2005. The agency provides means tested grants to children up to the age of 18 and to older people over 60 (Gutura, 2012).

The number of recipients has grown from 2.6 million to over 16.8 million (SASSA, 2013) and make up more than half the income of the poorest $20 \%$ of households (Department of Social Development, 2010). While KwaZulu-Natal tops the provinces with more than 3 million recipients, the Eastern Cape comes second with more than 2.6 million. In October 2009 , it was estimated that $22 \%$ of South Africans were receiving grants and that adult women comprised a third of grant recipients. Also, about $10 \%$ of recipients received more than one type of grants and about $59 \%$ of all poor children were receiving social grants by October 2009 (SASSA, 2009). Table 1 shows the growth in the number of recipients per province over a five year period (2008/2009 to 2013). KwaZulu-Natal, Eastern Cape, Gauteng and Limpopo provinces according to the table have the highest recipients, each with more than two million. This is a reflection of poverty in these provinces.

Table 1: Number of recipients for the past five years in different provinces (2008/2009-2013)

$\quad$ Province
KwaZulu-Natal
Eastern Cape
Gauteng
Limpopo
Northern Cape
Mpumalanga
Western Cape
Free State
North West
Total

Total

$\mathbf{2 0 0 8 / 0 9}$
$3,302,953$
$2,325,456$
$1,530,018$
$1,905,435$
329,367
974,645
884,630
752,694
$1,020,906$
$13,026,104$

Number of recipients per year

$\begin{array}{cccc}\mathbf{2 0 0 9 / 1 0} & \mathbf{2 0 1 0 / 2 0 1 1} & \mathbf{2 0 1 1 / 2 0 1 2} & \mathbf{2 0 1 3} \\ 3,584,885 & 3,710,581 & 3830403 & 3,868,366 \\ 2,516,001 & 2,585,593 & 2664319 & 2,680,384 \\ 1,735,415 & 1,825,491 & 1,948402 & 2,183,655 \\ 2,071,881 & 2,162,624 & 2141205 & 2,138,576 \\ 1,104,138 & 1,120,774 & 1175250 & 1,403,488 \\ 1,053,990 & 1,090,087 & 1353282 & 1,403,488 \\ 1,065,135 & 1,155,483 & 1249727 & 1,317,851 \\ 844,052 & 890,886 & 928178 & 937,178 \\ 367,613 & 387,820 & 404939 & 420,595 \\ 14,343,110 & 14,935,832 & 15595705 & 16,054,955\end{array}$

Source: Extracted from SASSA, 2013:12

The value of the grant has steadily been increasing to keep pace with the inflationary situation of the country. As shown on Table 2, most of the grants amount to R1260 per month (care dependency, old age, disability, and war veteran grants). Child support and grant in-aid are valued each at R290 and R800 for foster care grant per month (as from April $1,2013)$. Table 2 shows the steady increase in the values of these grants over a period of five years (2008/2009 to 2013). 
Table 2: Value of monthly social grants payable to recipients from 2010-2013

\begin{tabular}{|l|c|c|c|c|}
\hline \multirow{2}{*}{\multicolumn{1}{|c|}{ Grant type }} & \multicolumn{4}{c|}{ Grant value } \\
\cline { 2 - 5 } & $\mathbf{2 0 1 0}$ & $\mathbf{2 0 1 1}$ & $\mathbf{2 0 1 2}$ & $\mathbf{2 0 1 3}$ \\
\hline Grant in Aid & R250 & R260 & R280 & R290 \\
\hline Child Support & R250 & R260 & R280 & R290 \\
\hline Foster care Grant & R710 & R740 & R770 & R800 \\
\hline Care Dependency & R1080 & R1140 & R1200 & R1260 \\
\hline Old age Grant & R1080 & R1140 & R1220 & R1260 \\
\hline Disability grant & R1080 & R1140 & R1200 & R1260 \\
\hline War veterans & R1050 & R1140 & R1220 & R1260 \\
\hline
\end{tabular}

\section{Source: Extracted from SASSA, 2013}

The impact of social grants has widely been documented and the results show that they permit people and families to avoid destitution and have a significant positive effect on consumption and welfare. Social grants have helped in the reduction of South Africa's poverty gap (Tanga \& Gutura, 2013). It has also been found that social grants support development, including reducing poverty as well as improved levels of nutrition, health and education for grant recipients and their children (Tanga, 2008).

\section{Study Area and Methods}

The study was conducted in Nkonkobe Municipality of the Eastern Cape Province. A multi-stage sampling design was adopted for this study. The first stage was to find out the total number of households, wards and villages in each major area. The list of households with the number of wards and villages was collected from the Municipal Office. Nkonkobe municipality is divided into four major areas which include Fort Beaufort, Alice/Hogsback, Middledrift and Balfour with six, seven, seven and one wards respectively. At the second stage, eight wards were randomly selected; two (wards 4, 20) from Fort Beaufort; wards 2, 10, 13 from Alice/Hogsback; in Balfour, the only available ward was picked; and Middle-drift wards 5 and 19 were selected. The number of wards selected per each major area was based on the proportion of the total number of wards. As Table 2 shows, Fort Beaufort comprises of 6 wards; Alice/Hogsback, 7 wards; Balfour 1 ward; Middledrift 7 wards and respectively made up of 50, 75, 8, 50 villages. Table 2 further indicates that there were 36115 households and 44743 social grant recipients in Nkonkobe municipality. With a total population estimated at 145,000 inhabitants (Stats SA, 2012), it is assumed that each household comprised approximately four individuals and also at least one social grant recipient and this later proved to be the case (with a ratio of 1.4 recipients per household).

Thirty-seven (37) villages were then randomly selected from the chosen wards as shown in Table 3 . Households were selected from each of the selected villages using systematic random sampling and these comprised of 381 households from Fort Beaufort, Alice/Hogsback with 404, Balfour 16, and 299 from Middle-drift. Therefore, a total of 1100 households selected made up the sample of the study.

Table 3: Multi-stage sampling design

\begin{tabular}{|c|c|c|c|c|c|c|c|c|}
\hline Major area & $\begin{array}{c}\text { Total No. } \\
\text { of wards }\end{array}$ & $\begin{array}{c}\text { Ward } \\
\text { numbers }\end{array}$ & $\begin{array}{c}\text { Ward no. } \\
\text { selected }\end{array}$ & $\begin{array}{c}\text { Total no. of } \\
\text { villages }\end{array}$ & $\begin{array}{c}\text { No. of villages } \\
\text { selected }\end{array}$ & $\begin{array}{c}\text { Total no. } \\
\text { of hhs* }\end{array}$ & $\begin{array}{c}\text { Total no. of } \\
\text { recipients.** }\end{array}$ & $\begin{array}{c}\text { No. of hhs } \\
\text { selected }\end{array}$ \\
\hline $\begin{array}{c}\text { Fort } \\
\text { Beaufort }\end{array}$ & 6 & $\begin{array}{c}3,4,7,8, \\
20,21,\end{array}$ & 4,20 & 50 & 10 & 12506 & 16121 & 381 \\
\hline $\begin{array}{c}\text { Alice / } \\
\text { Hogsback }\end{array}$ & 7 & $\begin{array}{c}2,6,10,11, \\
12,13,15\end{array}$ & $2,10,13$ & 75 & 15 & 13259 & 17237 & 404 \\
\hline Balfour & 1 & 7 & 1 & 8 & 1 & 549 & 604 & 16 \\
\hline Middle drift & 7 & $\begin{array}{c}1,5,14,16, \\
17,18,19\end{array}$ & 5,19 & 50 & 10 & 9801 & 10781 & 299 \\
\hline Total & $\mathbf{2 1}$ & $\mathbf{2 1}$ & $\mathbf{8}$ & 183 & 37 & 36115 & 44743 & 1100 \\
\hline
\end{tabular}

* Households

** Grant Recipients

This sampling method can be defined as a statistical method involving the selection of sample households from a larger 
population according to a random starting point and a fixed periodic interval for $32^{\text {nd }}$ household selected from the total population for inclusion in the sample. The selected households were included in the sample only upon the enquiry and confirmation that there was at least a household member receiving one type of social grant or the other. However, all the selected households had at least one member receiving at least one type of social grant. As a result, there was no need to have substitute households or additional list of replacements over and above the selected households. Although costly and time-consuming, there were multiple follow-ups or increased contact efforts on respondents who could not be initially interviewed. Research assistants were also mindful of the time of the survey which was mostly in the evening. For the selection of respondents from each household, only the senior most adult member was included in the sample (one respondent per household). When the father was available at the time of data collection, he was included. When the father was absent, the mother; when both parents were absent, the eldest son or daughter; when the eldest son or daughter was absent, the available senior among the other sons / daughters was selected and interviewed.

A semi-structured questionnaire was designed and administered to the cross-sectional sample $(n=1100$ recipients of social grants) which was drawn from a population of 44, 843 made up of 19,980 male and 24,763 female recipients of social grants in the municipality (Statistics South Africa, 2012). Since most of the recipients were Isi-xhosa speaking, the questionnaire was administered in Isi-xhosa after it was back translated from English to Isi-Xhosa and to English. The questions covered areas such as demographics, socio-economic information, households and individual needs, type of social grants, household income, responsiveness of grants to household needs and living conditions before and after the financial crisis.

Prior to undertaking the study, a list of all councillors was obtained from the municipal office and letters were written to all the Nkonkobe Municipality Councillors and Community Development Workers about the research and requesting for permission to undertake the research. Furthermore, because undertaking this study deals with human subjects, ethical issues like anonymity, privacy and confidentiality were duly considered and strictly observed. Voluntary informed consent was acquired from all respondents before the commencement of the administration of the study instrument. Finally, ethical clearance was obtained from the University of Fort Hare.

Data collection was undertaken by five trained research assistants. Data were collected from June to September 2012. Before proceeding to collect data for the study, a pre-test was conducted on the draft questionnaire, using a sample of 25 respondents selected systematically from five villages within two wards other than those that the actual study was carried out. After the pre-test, the questionnaire was fine-tuned with the modifications wherever necessary. The research assistants did not encounter difficulty in obtaining the data from the respondents, especially as the respondents shared the same language, IsiXhosa. The vast majority of the Nkonkobe Municipality are IsiXhosa speakers with only a handful of Afrikaans speaking inhabitants. Being a quantitative study, data analyses were performed using the Statistical Package for the Social Sciences (SPSS). Frequency distribution tables were used to summarise pertinent information from key variables.

\section{Findings}

The results are presented according to the demographic characteristics of respondents or recipients, the type of grants and household income and perceived impact of the crisis on household needs.

\subsection{Demographic characteristics of respondents}

Data were collected from 1100 grant recipients from 37 communities around Nkonkobe municipality represented by the four major areas of the municipality as shown on Table 4. The 1100 respondents were made up of 305 males and 795 females, respectively representing $28 \%$ and $72 \%$. Table 4 shows that $46 \%$ of respondents were never married, followed by $18 \%$ of those who were widows. Those married constituted $16 \%$ of the respondents and the rest were either divorced/separated or cohabitating. Furthermore, Table 4 reveals that $74 \%$ of the respondents were head of households with females and males. The respondents also reported that $18 \%$ of mothers serve as head of their households and followed by fathers with $4 \%$. Concerning education, $77 \%$ had been to secondary school made up of $78 \%$ females and $73 \%$ males. This was followed by those with primary education qualification with $12 \%$ and those at the tertiary level constituted only $6 \%$. 
Table 4: Demographic characteristics of respondents $(n=1100)$

\begin{tabular}{|l|c|}
\hline \multicolumn{1}{|c|}{ Characteristics } & Percentage \\
\hline Major area of municipality & 37 \\
Alice/ Hogsback & 35 \\
Fort Beaufort & 01 \\
Balfour & 27 \\
Middledrift & \\
Marital status & 24 \\
Never married & 46 \\
Currently married & 16 \\
Divorced/separated & 12 \\
Widowed & 18 \\
Cohabitation & 7 \\
Other & \\
Household head & 74 \\
Myself (respondent) & 18 \\
Mother & 4 \\
Father & 1 \\
Grandfather & 2 \\
Grandmother & 1 \\
Aunt & 1 \\
Other & \\
Level of education & 12 \\
Primary & 77 \\
Secondary & 6 \\
Tertiary education & 4 \\
Vocational training & 2 \\
University degree & 0 \\
Other & \\
\hline
\end{tabular}

NB: Decimal points have been rounded to the nearest whole numbers

The mean age of respondents was 46 years with a standard deviation of 13.70. Similarly, the total mean of respondents' household size was about 5 people per household with a standard deviation of 1.88.

\subsection{Type of grants and household income of recipients}

Table 5 indicates that the majority (48\%) of the respondents were receiving child support grant valued at R290 (US\$29 exchange rate as of October 2013) with female recipients constituting up to $56 \%$ compared to only $28 \%$ for males. This was followed by old age grant with $34 \%$ recipients whose value is R1260 (US\$126). Here, the male recipients made up $52 \%$ whereas female recipients constituted only $28 \%$. The rest of the respondents were receiving other types of social grants with war veterans and grant-in-aid being the least being received.

Table 5: Percentage of respondents receiving different grants according to gender

\begin{tabular}{|l|c|c|c|}
\hline \multirow{2}{*}{ Grant type } & \multicolumn{3}{c|}{ Gender } \\
\cline { 2 - 4 } & Male $(\mathbf{n = 3 0 5})$ & Female $(\mathbf{n = 7 9 5 )}$ & Both sexes(n=1100) \\
\hline Old Age Grant & 52 & 28 & 34 \\
\hline Disability grant & 26 & 11 & 16 \\
\hline War veterans grant & 2 & 1 & 1 \\
\hline Grant in Aid & 0 & 1 & 1 \\
\hline Child Support grant & 28 & 56 & 48 \\
\hline Foster care Grant & 1 & 10 & 7 \\
\hline Care Dependency Grant & 4 & 7 & 6 \\
\hline
\end{tabular}

NB: Decimal points have been rounded to the nearest whole numbers

Mean duration of how long respondents have been receiving grants was about 7 years. About $52 \%$ of respondents revealed that they have other household members who were receiving one type of grant or the other. More males, $53 \%$ 
than females (51\%) reported other household members receiving grants in addition to theirs. Only $36 \%$ of respondents were investing part of their grant money into some form of economic activities. More men (47\%) invested compared to women $(32 \%)$ in various activities including subsistence farming, gardening, poultry, and piggery and saving schemes among others. Of the $36 \%$ of grant money being invested, bank savings and other saving schemes made up $59 \%$ of investment with males and females saving $57 \%$ and $60 \%$ respectively. This is followed by gardening projects and poultry farming respectively at $14 \%$ and $13 \%$ and these activities were slightly dominated by male respondents. Various reasons were advanced by $64 \%$ of respondents who were not investing grant money and some include the fact that the money is too little, no knowledge of business activity or acumen and no space in the villages.

About $58 \%$ of respondents said that their average household income ranged from R501-R1500. Male respondents accounted for $66 \%$ while females made up 55\%. Nineteen per cent and $21 \%$ revealed that their average household income stood at up to R500 and R1501-R3000 respectively. About 80\% maintained that they would need a further R3100 and above, monthly to adequately meet the needs of their households. Others stated various amounts of money needed that will make their households to satisfactorily meet their current demands given the financial downturn and constant high prices of food and fuel.

\subsection{Perceived impact of the financial crisis on living conditions}

Respondents were asked whether they have ever heard of the financial crisis and all of them answered in the affirmative. Eight-seven per cent of them understood very well the consequences and impact of the crisis on their lives; women and men were represented by about $90 \%$ and $79 \%$ respectively. Table 6 shows the assessment of the financial crisis on respondents before and during/after the crisis. Regarding the grants' meeting the needs of households before the crisis, $66 \%$ of all the respondents agreed that they were. Of these, the males had a larger percentage (74\%) as against $62 \%$ of females. The period during/after the crisis, $56 \%$ of males answered in the affirmative relating to the meeting of their needs with the grant money as compared to only $39 \%$ females. General analysis shows that in total, $65 \%$ of all the respondents said yes, the grants were meeting their needs during/after the crisis, a very insignificant drop of one per cent.

Relating to the positive impact of the grant on life, only $28 \%$ males accepted the fact that the grants had an impact with $46 \%$ females who confirmed the same impact before the crisis. Generally $41 \%$ of all the respondents said yes to the grants having an impact on their lives. The number decreased thereof, during/after the period of the crisis whereby only $24 \%$ and $41 \%$ of the male and female respondents respectively, said that the grants had an impact. The respondents indicated the reasons why there was no impact before the crisis; the males had a greater percentage of respondents who said that the money was little (52\%) with females holding a lesser percentage of $26 \%$. Those who indicated that it was because of the fact that the household depended solely on the grants were $72 \%$ of females and $46 \%$ of males. To show that it was because the grants were being used for other things than basic household needs, there was a relatively low percentage for both male and female respondents.

A further analysis portrays that $3 \%$ of all the respondents indicated that there were adults who went hungry before the crisis. However, five per cent of the male respondents showed that there were adults who went hungry before the crisis with $2 \%$ females who held the same view. The percentage of respondents who indicated that due to the financial crisis there were adults who went hungry rose to $7 \%$ made up of $10 \%$ males compared to $6 \%$ females.

Table 5: Assessment of perceived impacts of the financial crisis on social grant recipients

\begin{tabular}{|l|c|c|c|c|}
\hline \multicolumn{2}{|c|}{ Question } & \multicolumn{3}{|c|}{ Yes response only } \\
\hline \multirow{3}{*}{ Grant meeting household needs? } & Period of crisis & Male (\%) & Female (\%) & Total (\%) \\
\cline { 2 - 5 } & Before & 73 & 62 & 66 \\
\cline { 2 - 5 } & During/After & 56 & 39 & 65 \\
\hline \multirow{2}{*}{ Positive impact of grant on life? } & Before & 28 & 46 & 41 \\
\cline { 2 - 5 } & During/After & 24 & 41 & 36 \\
\hline \multirow{2}{*}{ Any adult went hungry? } & Before & 5 & 2 & 3 \\
\cline { 2 - 5 } & During/After & 10 & 6 & 7 \\
\hline \multirow{2}{*}{ Any child went hungry? } & Before & 4 & 2 & 3 \\
\cline { 2 - 5 } & During/After & 6 & 5 & 5 \\
\hline \multirow{2}{*}{ Was/is household consumption adequate? } & Before & 86 & 67 & 72 \\
\cline { 2 - 5 } & During/After & 62 & 39 & 45 \\
\hline Was/is housing conditions adequate? & Before & 86 & 67 & 72 \\
\hline
\end{tabular}




\begin{tabular}{|l|c|c|c|c|}
\hline & During/After & 63 & 37 & 44 \\
\hline \multirow{2}{*}{ Was/is household clothing adequate? } & Before & 87 & 68 & 73 \\
\cline { 2 - 4 } & During/After & 61 & 37 & 44 \\
\hline \multirow{2}{*}{ Was/is children's schooling adequate? } & Before & 59 & 62 & 61 \\
\cline { 2 - 4 } & During/After & 41 & 32 & 34 \\
\hline
\end{tabular}

NB: Decimal points have been rounded to the nearest whole numbers

Before the crisis, $4 \%$ of the males said there were children who went hungry and in the female category, only $2 \%$ mentioned same. However, after the crisis $5 \%$ of females showed that there were children who went hungry and for the males it was $6 \%$ who said so. In summation before the crisis, $3 \%$ of all the respondents said children went hungry and during/after the crisis, there was an increase to $5 \%$ of children who were going hungry due to the impact of the crisis. Furthermore, $86 \%$ of males stated that the household consumption was adequate before the crisis with $67 \%$ of females saying the same. However, during/after the crisis, $45 \%$ of all the respondents said that household consumption was adequate and this was made up of $62 \%$ of males and $39 \%$ of females. Relating to the household housing conditions being adequate, majority of the males (86\%) indicated that the grants were adequate with $67 \%$ of females agreeing. During/after the crisis, only $63 \%$ of males said the grants were adequate and for the females it was only $37 \%$ who said that the money from grants was adequate to cater for the household housing conditions. Total analysis shows that $72 \%$ said yes to the housing conditions being adequate before the crisis but during/after the crisis, only $45 \%$ said yes.

Also, the household clothing conditions before the crisis were characterised by being adequate as shown by $73 \%$ of the respondents. In relation to gender, it was $87 \%$ of males and only $68 \%$ of females who highlighted that the grant money was adequate for household clothing. Sixty one per cent of males argued that after the crisis it was adequate and only $37 \%$ of females held the same view. According to the total percentage after the crisis, only $44 \%$ said yes to the household clothing conditions being adequate. Children's schooling before the crisis was highlighted by the majority of both males and females representing $59 \%$ and $62 \%$ respectively as being adequate. However, after the crisis, only $34 \%$ of all the respondents agreed that children's schooling was adequately cared for; represented by $41 \%$ of males and $32 \%$ of females.

\section{Discussion}

The impact of financial crisis on social grant recipients is felt at the different household levels which are already struggling to maintain existing commitments. Although Samson et al (2004) maintain that social grants have significantly reduced poverty gap in South Africa, there are still serious challenges regarding poverty alleviation. Given the high inflation rate $(6.1 \%$ as of November 2012) and the ever increasing food and fuel prices, the values of the grants have become a serious concern as their monetary values cannot meet the needs of the African households. African households are known for pulling together their incomes and living in collectivity and not individualistic as in the west. In the African traditional spirit of sharing and reciprocity, vulnerable extended family members, orphans and less privileged community members benefit from this largess of sharing (Tanga, 2013). This is shown by the results whereby $51 \%$ of households had more than one member receiving one type of grant or the other and these are pulled together for the benefit of the entire households. The socio-economic situation of recipients and their households has continued to deteriorate because of the 2007/2008 and the 2011 Euro zone crises. The results show that $80 \%$ of respondents would need more than R3000 to meet their monthly household needs. The Euro zone crisis has affected consumer spending in South Africa as the country is closely linked to the developed countries, especially the Euro zone which is suffering from a debt crisis. The largest brunt of the 2007/2008 financial crisis was felt more by women than men because as Cohen (2010) maintains, they feel insecure and vulnerable not being able to adequately provide for the needs of their households. During such crisis, the poor and vulnerable people such as grant recipients are the losers through high prices and reduction either in value of their grants and other public social services.

The results of this study have shown that the majority of males compared to females indicated that the money from the grants is meeting their needs, as well as the state of their households regarding hungry adults and children, consumption, clothing, housing conditions and children's schooling. This is a strong indication of the important role of women in household responsibilities than that of men in Africa. The female as the 'figure' head of the household feels the impact of the financial crisis as she is the centre of the family; taking care of the needs of children and other dependant family members. While most men probably used their grant money on social activities, women are more devoted to caring for their households and extended families. This also explains the reason why up to $72 \%$ of females reported that other family members depended on their grant income compared to only $46 \%$ of males. The crisis has increased strains 
on females trying to meet their responsibilities for family care. If only $59 \%$ of poor children are receiving grants (Department of Social Development, 2010), it implies that the rest of the $41 \%$ must be relying on the recipients of the grants, most likely females and/or on other forms of assistance from other sources. Similarly, if the Eastern Cape Province has $30.8 \%$ of inhabitants living in poverty and only $22 \%$ are receiving grants which constitute income of the poorest $20 \%$ of households (Department of Social Development, 2010), it means that the rest of the $88 \%$ should be depending on family members who might be grant recipients and/or on other sources of support.

The results from the study show that before the crisis the recipients of the grants were able to cope but during/after the crisis they were struggling to cope as the monetary value of grants decreased with high inflation. This shows that the grant recipients were affected by changes in prices as a result of the financial crisis, hence food consumption was decreased. Experience shows that when families are facing financial and other problems in most African societies, the men take out their frustrations on women and children through battering. This may explain the high prevalence of domestic violence in South Africa, despite the Domestic Violence Act, Act 116 of 1998 protecting the vulnerable women and children (Van der Hoven, 2001). There is also a high probability that many unemployed people in the rural areas are migrating to cities in search of job opportunities that are very rare. The consequences of not finding such anticipated jobs include the contribution to the already high crime rate in the country. Social grants play an integral role in militating against the impact of poverty. However, resources to address the poverty impacts of the financial crisis are limited with the government feeling the impact also. It is maintained that the crisis has slowed down economic growth in Africa, especially sub- Saharan Africa because of a decreased in economic activities and an increased in debts (AfricaFocus Bulletin, 2010). There have also been incessant strikes in South Africa demanding better service delivery and as the World Bank Group Staff (2009) aptly stated, there is general deterioration of public services in Africa resulting especially from the financial crisis.

Furthermore, South Africa has continued to experience jobs losses, especially in the textile and mining industries and most of those affected either become recipients of social grants directly or indirectly through depending on recipients who are relatives. Espey, Harper and Jones (2010) appropriately stated that many developing countries are experiencing the impact of the global financial crisis with mass unemployment, workers being laid off, declining remittance flows and reduction in government spending on social services. This raises the issue of sustainability of these grants in South Africa with an annual increase rate of about 16\% (SASSA, 2013). The medium-term effects on social protection allocations are more likely to be significant, and it is apparent that the extension of social protection to those affected by the crisis is likely to be compromised by lack of resources. In a similarly vein, even the extension of existing programmes, planned prior to the financial crisis, might be limited by falling revenues and concerns regarding the control of budget deficit. Therefore, actual and anticipated falls in public revenues might constrain the social protection budget. As the literature revealed, developing country governments face tough decisions on what to prioritize in terms of public expenditure as deficits rise, including the provision of social protection. If inflation remains high, there is likely to be a real cut in social services spending, unless governments' budgets are significantly re-prioritized. The South African inflation rates before the crisis were $4 \%$ and $5 \%$ in 2005 and 2006 respectively. During the crisis, the rates were $6.5 \%$ and $11.3 \%$ in 2007 and 2008 respectively. In 2009 and 2010, the respective rates were 7.2\% and 4.5\%. As of November 2012, the inflation rate has increased to $6.1 \%$ (CIA Factbook, 2012).

Another impact of the financial crisis is a change in lifestyle, which is, forgoing of non-essential goods and services. This is what Gaerlan et al (2010) call letting go of non-essentials. It is hoped that these recipients have developed resilience and creativity. The results of this study show a complete reduction of spending on household housing condition, consumption, clothing and children's education. It is most unfortunate that education of children is also affected and the lack of education cripples the human capital of the society. It is most likely that the crisis has affected school attendance despite of government's feeding programmes. The worst case scenario as the literature shows is that girls in poor countries with pre-existing low female schooling are highly vulnerable to being pulled out of school as households try to cope with declining household incomes. It is most likely that as in other low income countries, girls and boys may similarly drop out of school because households can no longer afford school fees and/or children's needs to contribute with their labour to household income as Horn (2010) suggests.

It is deceptive to believe as the results suggest that $36 \%$ of recipients of grants invest, especially in saving accounts; it is simply because they are paid through the banks and post offices. It would have been interesting if these investments were genuine and yielding enough income to the investors (recipients) so as to counter the current argument that social grants are creating a dependency culture. Evidence from the Eastern Cape has shown that indeed the financial crisis has had a negative impact on the recipients who are from financially vulnerable households and who struggle with high consumption expenditure. Nonetheless, it is apparent that the impact of the financial crisis has not 
completely reversed the positive impact of the grants. Yet it is evident that the financial crisis did indeed have an impact on monetary poverty in South Africa.

\section{Conclusion}

The financial crisis of 2007/2008 should be regarded as the worst economic downturn in the history of the world after the World War II given its negative impact on households' consumption, production and expenditure. The crisis together with the 2011 Euro zone debt crisis is likely to continue to lead to increased poverty and economic vulnerability of households across South Africa. The crises have fostered the already existing intergenerational poverty in South Africa among social grant recipients. The worst household living conditions affected by the crisis include household food consumption, housing conditions, household clothing situation and children's schooling. Many households have been forced to adjust to the crisis by forgoing some of the things that they were using and/or reducing the rate or extent of usage. However, the prioritisation and planning of these needs by rural uneducated masses is something that needs scrutiny. The current situation is one that will encourage continuous long time dependency on social grants. Similarly, the results support the literature that many poor women and men in the developing world are feeling the financial crisis most potently through its impact on their ability to earn income and increasing prices which together can result in considerable household stress.

Although women constitute the majority of social grant recipients, they are mostly receiving grants of low value such as the child support grant which is only R260 (US\$26 - October 2013 exchange rate) per month. Yet, these women bear the unfair burden of caring for the family and other household members who are vulnerable. It is therefore, expected and not surprising to note that the financial crisis is affecting all recipients of social grants in South Africa, though with varying degrees and impacts on male and female grants recipients. This is in spite of the fact that they are receiving the same amount of money in social grants. Therefore, the results have shown the pivotal role that African women play in the livelihood and survival of their households with or without men. It is also reasonable to state that the pulling together of household income has not been able to adequately meet household needs of recipients. This is especially with the combination of the 2007/2008 financial and 2011 Euro zone crises which have both orchestrated constant high prices of food and fuel with negative multiplier effects on the citizens and countries.

In the light of the results from this study, to prevent temporary household coping mechanisms from affecting future consumption there is need for an increase in food security in households. This could be achieved through encouraging joint or family gardening projects supported by extension workers of the Department of Agriculture. Loans to these groups would enhance these gardening projects and perhaps help in letting social grant recipients to graduate from grant receiving in the near future. In the short run, it is necessary to strengthen social grants to help families to offset drops in income and also to assist with items in the family budget that directly affect children, such as health, nutrition and education.

\section{Acknowledgements}

The authors are grateful to the Govern Mbeki Research and Development Centre of the University of Fort Hare for the financial support of this study.

\section{References}

AfricaFocus Bulletin (2010). Economic Report; 2010. Available from http:/luneca.org/eca_resources/Publications/books/era2010] (June 23,2012).

Altman, M.; Hart, T. \& Jacobs, P. (2009). "Household food security status in South Africa". Agrekon, Vol. 48 (4). Available from [http://www.hsrc.ac.za/research/output/../6182_AltmanHouseholdsecuritystatus.pdf ] (August 2, 2011).

Bhorat, H. (1995). "The South African social safety net: past, present and future". Development Southern African Journal, Vol. 12 (4).

Bhorat, H. \& Van der Westhuizen, C. (2010). "Poverty, Inequality and the Nature of Economic Growth in South Africa". In, Misra-Dexter, N. and February, J. (eds)Testing Democracy: Which way is South Africa going? Cape Town: IDASA.

CIA World Factbook (2012). Historical data graphs per year: South Africa (consumer prices) 2011. Available from [http://www.indexmundi.com] December 29, 2012.

Cohen, J. (2010). "How the global financial crisis reaches marginalised workers: the case of street traders in Johannesburg, South Africa". Gender and development, Vol. 18(2), pp. 277-289.

Committee for the Restructuring of Social Security (SASSA) (1997). Report of the Committee on the Restructuring of the Social Security System. South Africa: SASSA.

Community Agency for Social Enquiry (CASE) (2000). Phasing in the Child Support Grant, A social impact study. Johannesburg: CASE. 
Department of Social Development (2009). Progress Report. Available from. [http://www.socdev.gov.za/Documents/2009/April /progr.PDF] January 18, 2011).

Department of Social Development (2002). Progress Report. Available from [http://www.socdev.gov.za/Documents/2002/April /progr.PDF] (May 12, 2012)

Department of Social Development (2010). Progress Report. Available from [http://www.socdev.gov.za/Documents/2010 IApril/progr.PDF] (March 17, 2012).

Espey, J.; Harper, C. \& Jones, N. (2010). "Crisis, care and childhood: the impact of financial crisis on care work in poor households in the developing world". Gender and Development, Vol. 18(2), pp. 291-307.

Gaerlan, K.; Cabrera, M.; Samla, P. \& Santoalla, L. (2010). "Feminised recession: impact of the global financial crisis on women garment workers in the Philippines". Gender and Development, Vol. 18(2), pp. 229-240.

Gutura, P. (2012). "Are child social grants creating dependency culture among beneficiaries" A case study of Nkonkobe Muncipality, Eastern Cape (MSW dissertation).Alice: University of Fort Hare.

Legido-Quigley, H. (2003). The South African Old Age Pension: Exploring the role on poverty alleviation in households affected by HIVIAIDS. Paper read in a Conference held from 5-7 May, Antwerp in Belgium.

Midgley, J. (1996). Social Development: The Developmental Perspective in Social Welfare. London: Sage Publications

Organisation for Economic Cooperation and Development (OECD) (2010). Trends in South African income distribution and poverty since the fall of apartheid: Experts seminar. Cape Town: University of Cape Town.

Pelham, W. (2007). The politics behind the non-contributory old age social pensions in Lesotho, Namibia and South Africa. Cape Town: Chronic Poverty Research Centre.

Republic of South Africa (1996). Constitution of the Republic of South Africa, No 108 of 1996. Pretoria: Government Printers.

Samson, M.; Lee, U.; Ndebele, A.; Mac Quene, K.; Van Niekerk, I.; Gandhi, V.; Harigaya, T. \& Abrahams, C. (2004). "The social and economic impact of South Africa's social security system". Report commissioned by the Finance and Economic Directorate of the Department of Social Development. Economic Policy Research Institute (EPRI). Cape Town: Department of Social Development.

South African Social Security Agency (SASSA) (2013). Annual statistical report on social grants. Available from http://www.sassa.gov.za (July 24, 2013).

South Africa (1997). Social Welfare White Paper-Principles, guidelines, recommendations, proposed policies and programmes for developmental social welfare in South Africa. Tshwane, Government printers.

South African Social Security Agency (SASSA) (2009). Annual statistical report on social grants. Available from [http://www.sassa.gov.za]. September 2, 2011.

Statistics South Africa - Stats SA (2012). Poverty profile of South Africa. Application of the poverty lines on the Living Conditions Survey 2008/2009. Available from [http://www.statssa.gov.za (May 20, 2013).

Statistics South Africa - Stats SA (2013). Quartely Labour Force Survey. Pretoria: South Africa. Available from [http://www.statssa.gov.za (June 12, 2013).

Statistics South Africa: Social Grants: In-depth analysis of General Household Survey Data, Analysis. Pretoria: Statistics South Africa; 2010.

Tanga, P. T. (2008). "The impact of Old Age Pension on Households and Social Relationships". Review of Southern African Studies, Vol. 12 (1\& 2), pp. 184-215.

Tanga, P. T. (2013). "The impact of declining extended family support system on the education of orphans in Lesotho" (forthcoming in the African Journal of AIDS Research).

Tanga, P. T. \& Gutura, P. (2013). "The impact of child support grant on the participation in the labour market in the rural Eastern Cape". Social Work/Maatskaplike Werk, Vol. 49 (1), pp. 128-140.

Van der Hoven, A. (2001). "Domestic violence in South Africa". Act Criminologica, Vol. 14 (3), pp. 13-25.

Vorster, J.; Rossouw, H. \& Muller, G. (2000). Phasing out the State Maintenance Grant within the Context of Developmental Social Welfare. Research Report to the Department of Welfare Stellenbosch, Data desk \& Department of Sociology, University of Stellenbosch.

World Bank Group Staff (2009). Protecting Progress: The Challenge facing Low income countries in the global recession. New York: World Bank. 
